\title{
FORMS, DEVELOPMENT AND THE APPLICATION OF MUSIC MEDIA IN THE KINDERGARTENS: A Comparative Study of Two Kindergartens
}

\author{
${ }^{\square}$ Totok Sumaryanto Florentinus \\ Study Program of Art Education \\ Post Graduate Program, Semarang State University, Indonesia \\ ఐE-mail: totokunnes@yahoo.co.id \\ Udi Utomo \\ Music Department, Semarang State University, \\ Sekaran Campus, Semarang 50229, Indonesia \\ E-mail: udi_utomo_unnes@yahoo.com
}

Received: October 18, 2015. Revised: November 29, 2015. Accepted: November 29, 2015

\begin{abstract}
This study was aimed at investigating the form of music media employed in the teaching and learning process (TLP) in the kindergartens, and the teachers' effort to develop and apply music media in the TLP. The researchers used a qualitative approach. The research was conducted in TK Hj. Isriati Baiturahman and TK Negeri Pembina Semarang. The subjects of the study were principals, teachers, staffs and students. In collecting the data, the researchers used three different techniques: interview, observation and documentation. Then, the researchers used data reduction, categorization and data interpretation to analyse the data. The result shows that the teachers in both schools have utilized varied music media in the TLP. In TK Hj. Isriati, the teachers used music media in the form of music composition and electronic equipment; and the new music instruments were used by the teachers in extracurricular activities. Meanwhile, the teachers in TK Negeri Pembina utilized music media, including music composition, music instruments and electronic equipment. The development of music made by the teachers was done by modifying lyrics, composing simple songs, utilizing rhythmical music instruments and employing electronic equipment in the TLP.
\end{abstract}

Keywords: form; media; music; kindergarten

How to Cite: Sumaryanto F., T., \& Utomo, U. (2015). Forms, Development and The Application of Music Media in The Kindergartens: A Comparative Study of Two Kindergartens. Harmonia: Journal of Arts Research and Education, 15(2), 101106 doi:http:/ /dx.doi.org/10.15294/harmonia.v15i2.4099

\section{INTRODUCTION}

The implementation of teaching and learning process (TLP) in kindergartens has never been apart from musical activities, even though it is still in the form of singing. This activity is conducted either inside or outside of the classroom (see Syahrul, 2010; Moeslichatoen, 2009, p.12-13).
Musical activities, as a kind of teaching and learning processes in the kindergarten and a combination of the various areas are expected to support the outcome of teaching and learning objectives in the kindergarten.

To create musical activities such as listening to music, singing, playing simple music instruments and others which 
are meaningful to the students, it needs teachers' skills to develop a plan and an implementation in the TLP. Some of the critical issues related to the teachers' skills concern: (1) the ability to determine the appropriate music experiences which relate to the themes and development aspects in the kindergarten, (2) the ability to design musical activities to be implemented, (3) the ability to determine kinds of music and songs that will be used as teaching media, and (4) the ability to define and use musical instruments that support the learning process.

Based on the explanation above, the research questions are outlined as follows: (1) how is the music media used in the TLP to be implemented in the kindergarten? And (2) how do the teachers develop and apply music media in the TLP in the kindergarten?

Musical activity is an important role in the kindergarten education program. Froebel, an expert of kindergarten believes the values of musical experiences for the students as written in his book, Mother Play and Nursery Songs. Based on his opinion, the students should be given as much singing and playing experiences through singing activities.

Moreover, Anderson (2004, p. 2) states that the kindergarten students are the most original composers. They create more music, explore it carefully, use more consistent and spontaneous music, and have a stronger motivation on music compared to the students in the higher level (adolescence).

Music, as one of the important activities in the TLP in the kindergarten is considered to be affected the child's personal development which involve some development aspects such as motoric, language, emotional, social, and intelligence. In addition, it is also due to the music as a part of children's life, cultural heritage, and it is as tools to express themselves (Moeslichatoen, 2009, p. 12-13).

The scope of the TLP in the kindergarten involves behavior formation through the implementation of moral de- velopment of Pancasila, religion, discipline, feelings/ emotions, and social skills, as well as the development of basic skills through activities prepared by the teachers which include the development of language skills, critical thinking, creativity, skill, and physic.

To achieve the goals of the TLP in the kindergarten, the teachers have established varied themes. The themes are (1) I, (2) senses, (3) family, (4) houses, (5) schools, (6) food and drink, (7) clothing, (8) cleanliness, (9) plants, (10) vehicles, (11) occupation, (12) recreation, (13) water and air, (14) fire, (15) countries, (16) communication tools, (17) natural phenomena, (18) sun, moon, stars, and earth, and (19) life in cities, villages, coastal areas and mountain (Moeslichatoen, 2009, p. 13-14).

The varied themes are delivered to the students through integrated activities by including music as one of the components. Music activities such as listening music, responding music with its rhythmical motion, singing, reading music notation, and playing simple musical instruments are the activites in the TLP, the purpose of which is to establish behavior (especially through messages of the lyrics), and to develop their basic skills such as creativity, language, thinking, skill, and physic (through melody, rhythm, harmony, lyric and expression) (Safrina, 1999, p. 125-166).

In order to achieve its objectives, it needs the teachers' skills to develop and apply the existing music media. The media are anything (hardware and or software) which relate to music, applied as teaching media since they can stimulate the students' thinking, feeling, attention and willingness to promote effective and efficient TLP. In the context of teaching and learning process in the kindergarten, it emphasises on the process (not the goal).

Music media can be devided into three main forms: music composition, music instruments and electronic equipment. The composition of music is in the forms of vocal music, works of instrumental music, or a mixture of both. Based on the 
character, the instrument can be classified into two types: musical rhythmic and melodic instruments. The rhythmic musical instrument is a musical instrument that can only be used as a rhythmical support. For example, it can be seen from drums, drum, tambourine, castanyet, guiro, cymbals, and others. Furthermore, the melodical music instrument can function not only to support but also to play melody. For example, it can be in the forms of flute, pianika, glockenspiel, guitar, harmonica, and others.

Based on the sound sources, music instruments can be divided into several groups: (1) an instrument derived from human (limbs) such as clapping, pounding feet, excerpting fingers, and others, as well as human voice for more specific, (2) idiophone instruments such as calung, xylophone, marimba, glokenspiel, chimes, maracas, tambourine, castanyet, triangle, guiro, etc., (3) aerophone instrument, such as flute, clarinet, saxophone, trumpet, trombone, pianika, harmonica, etc., (4) membranophone musical instruments such as stringed drum, bass drum, bongo, conga drum, drums, terbang, etc., (5) cordophones instrument such as guitar, mandolin, violin, zither, piano, harp, fiddle, etc., and (7) electrophone musical instruments such as elerctronic organ, electone, syntesizer, sound effects, electric guitars, and others (Safrina, 1999, p. 15-18).

Electronic equipment included as music media (hard ware) are radio, tape recorder, television, cassettes music recorder, music CDs, music VCD, MP3, LD music, sound system and others. Some of those can be used as media for listening or watching music (Rinanto, 2005, p. 44-63).

\section{METHOD}

The study used a qualitative approach. The setting of the study was at TK Hj. Isriati Baiturahman and TK Negeri Pembina Semarang. The principals, teachers, staffs and students became the subject of the study. To collect the data, the writer used interview, observation, and documentation. The qualitative data was analysed for its validity using the degree of trustworthiness, triangulation and also theory. The technique to analyse data used three phases. They were data reduction, categorization, and data interpretation (verification / conclusion).

\section{RESULT AND DISCUSSION}

\section{The Application of Music Media in the TLP in TK Hj. Isriati Baiturahman}

The forms of music media including: (1) music composition, (2) music instruments, and (3) electronic equipment have been implemented as a part of the TLP in TK Hj. Isriati Baiturahman. The utilization of those music media could be seen from their varied activities. Vocal works like children's songs have always been used as teaching media in the pre activity for 30 minutes started from 07:00 to 07:30. It was held in the hall attended by all students in class $\mathrm{A}$ at the same time (A1, A2, A3, and A4). Not only to support pre activity, the children's songs were also used for other purposes such as to strenghthen messagges for the students and to improve students's vocal skills (singing lesson).

In addition, there were also some other TLP that utilized music composition such as musical composition and instrumental mixture. Based on the data, the use of music instrument as teaching media in TK Hj. Isriati was implemented in the extracurricular activities. Classroom teachers or the students only used clapping hands in their pre activity, main activity, post activities and singing activity to support the TLP.

There were various numbers of musical instruments used in the extracurricular activities, among others were: (1) a set of musical instrument drum band, (2) a set of angklung musical instrument, and (3) keyboard to support singing activities. There were some activities in which electronic equipment was used in TK Hj. Isriati such as (a) before the class began around 6:00 to 7:00, the teachers used music media to welcome the students' arrival and when 
students were playing outside while waiting for the bell rang. It was the recording of children's songs in the form of either instrument or mixture (vocal with musical accompaniment). In doing so, the teachers played the songs using a tape deck with its sound system in order all students could listen, (b) teachers also used electronic equipment as the teaching media in the TLP on pre-activity, main activity and post activity. The electronic equipment used by the teachers during the pre activity in the hall were a mic wereles and a big tape functioning as sound control. When the TLP was held in the classroom, the teachers also used loudspeakers such as mic wereles, amplifier and speaker.

Those employing electronic equipment as music media in the TLP in TK $\mathrm{Hj}$. Isriati were the teachers teaching dance and music. On the dancing activity, the electronic equipment used as music media was tape and cassette recorder as musical accompaniment. While in the music learning activities, there were a keyboard (Roland EM 25) and two electrical equipments, a tape as sound control and mic wereles for students to sing in turns.

The Effort of Teachers to Develop and Apply Music Media in the TLP in TK Hj. Isriati Baiturrahman Semarang

An effort to develop music media in the TLP undertaken by the teachers in TK $\mathrm{Hj}$. Isriati was still by using music composition media in the forms of childrens's songs and sound system. The development of children's songs could be seen while the teachers were doing improvisation of the lyrics and the TLP. It happened when they found interesting things or events that needed appropriate songs with their proper lyrics to reinforce the atmosphere of the TLP. Beside modifying the lyrics, the teachers also created their own songs.

On the other hand, to develop electronic equipment in the form of sound system as teaching media in the pre-activity, main activity and post activity the teachers always utilized the existing sound system. It was due to its precision tone, rhythm and articulation in reciting the lyrics by the teachers in order the students could hear and follow.

\section{The Implementation of Music Media in TK Negeri Pembina Semarang.}

Similar to TK Hj. Isriati, music media were in the forms of (1) music composition, (2) music instruments, and (3) electronic equipment which have become an important part of the TLP. The details are as follow:

The utilizaion of music compositions as teaching media in TK Negeri Pembina involved vocal, instrument and mixture works. Vocal works in the forms of children's songs were always used as teaching media while the students were doing pre-activity at 07:00 in the morning.

Moreover, the teachers also used mixture works in the main activities. For example, the students were doing some ativities such as drawing, coloring and sticking. Meanwhile, the teachers also played children's songs to accompany the students' activities. Then, the teachers of TK Negeri Pembina kalso utilized music composition both instrumenal and mixture music especially by those teaching dance. They used it as accompaniment "move and song" for class A. Furthemore, the teachers used folk and "dolanan" songs to accompany "move and song" learning for the male students of class B.. For the female students of class B, musical composition for gamelan (gending) was used as learning accompaniment since the teaching material was the new dance creations.

Both classroom teachers in their main classes and art teachers in their classes in TK Negeri Pembina used isntrumental music. The classroom teachers in their pre-activity, main activity and post activity in the classroom utilized a number of music instruments such as (1) castanet, (2) maracas, (3) triangle, and (4) tambourine. Meanwhile, the art teachers used two main music instruments: a set of kulintang and angklung instruments. There were two main activities which utilized electronic equipment in TK Negeri Pembina: (1) at 
the TLP conducted by all classroom teachers and (2) at the TLP of music. The details are outlined as follows:

The use of electronic equipment as music media by the classroom teachers were conducted in the pre-activity, main activity and post activity. Mini compo as one of electronic equipment was used not only to play children's song recording to accompany the students while they were doing several acticities such as drawing, coloring, cutting, etc. but also to play cassette recorder either instrumental or mixture works in the rhythmic and physical activities.

The use of electronic equipment as music media in the art learning was conducted by the art teachers. The equipment was a tape deck or tape mini compo available in each class. It was to play music as accompaniment in the motion and song TLP, "dolanan" dance and new dance creations.

The Effort of Teachers to Develop and Apply Music Media in the TLP in TK Negeri Pembina Semarang

To develop music media which related to problems of choosing media, the use of varied media and teachers' creation in utilizing music media in TK Negeri Pembina were conducted by modifying the lyrics of the existing children's songs and creating simple songs of their own. The lyrics were adapted based on the existing themes in the TLP.

Finally, to develop the utilization of music media was done by developing rhythmic instrument including: 1) castanet, (2) triangle, (3) maracas, and (4) tambourine as well as tape recorder while the students were doing a number of activities such as drawing, sticking, cutting, coloring, printing and others.

\section{CONCLUSION}

The use of music media in the forms of: (1) music composition, (2) music instrument, and (3) electronic equipment has been conducted by the teachers both in TK Hj. Isriati and TK Negeri Pembina Sema- rang.

Music media in the forms of vocal, instrument and mixture works have been done by the classroom teachers in the TLP in TK Hj. Isriati Baiturahman Semarang. Otherwise, music media in the forms of instrument was still limited only by the use of natural instrument such as clapping. The use of musical instruments avaliable in the school was only conducted by extracurricular teachers such as singing, angklung and drumband. Electronic equipment such as sound system, tape recorder, cassette recorder have already been used by the classroom teachers both before the class started and in the TLP inside the classroom started by pre activity, main activity and psot activity by utilizing sound system as the loud speaker.

To develop the utilization of music media by the teachers in $\mathrm{TK} \mathrm{Hj}$. Isriati can be seen by their courage to modify the original lyrics based on the learning situations. Beside, they also created new songs based on the school needs and creations to utilize electronic equipment in many TLP.

On the other hand, music media in the forms of vocal, instrumet and mixture works have also been utilized by the classroom teachers in the TLP in TK Negeri Pembina Semarang. It was not only limited to use the natural instrument such as clapping, but also rhytmic instrument such as (1) castanet, (2) triangle, (3) maracas, and (4) tambourine. Then, the other music instrument was still used by those teaching music art. Finally, tape and cassette recorders as electronic equipment were used during rhytmic activities performed in the pre-activity, main activity and post activity.

The effort to develop the utilization of music media in TK Negeri Pembina was shown by the courage to modify the lyrics, to create simple songs, and to utilize rhytmic music instrument in the rhytmic and singing activities. Not only tape and cassette recorders, music media was also utilized to support the TLP in the classrooms. 


\section{REFERENCES}

Anderson, R.H. (2004). Pemilihan dan Pengembangan Media untuk Belajar. Jakarta: Raja Grafindo Persada.

Kristyana, L. (2014). Singing as a Strategy to Enhance the Ability to Speak for Early Childhood. Harmonia: Journal Of Arts Research And Education, 14(2), 123-130. doi:http://dx.doi. org/10.15294/harmonia.v14i2.3293.

Kusumadewi, L. \& Suharto, S. (2011). Peningkatan Hasil Belajar Seni Musik dengan Media Audio Visual melalui Metode Bervariasi. Harmonia: Journal Of Arts Research And Education, 10(2). doi:http://dx.doi.org/10.15294/harmonia.v10i2.63.

Mehmet, B. \& Mohamed S. S. (2010). Visual Arts Teaching in Kindergarten through 3rd-Grade Classrooms in the UAE: Teacher Profiles, Perceptions, and Practices. Journal of Research in Childhood Education, 24(4).

Moeslichatoen, R. (2009). Metode Pengajaran di Taman Kanak-kanak. Jakarta: Rineka Cipta.

Moleong, L.J. (2000). Metode Penelitian Kualitatif. Bandung: Remaja Rosda karya.

Olofsson, A.D. \& Lindberg, J. O. (2006). Whatever Happened to the Social Dimension?" Aspects of Learning in a Distance-based Teacher Training Programme. Springer Science and Business Media, Inc. 11(7) 20, retrived from http://search.proquest. com/docview/821861284/ 13CA558784 71FE0F804/4?accountid=34598.

Rohidi, R.T. (2000). Kesenian dalam Pendeka- tan Kebudayaan. Bandung: STISI Bandung Press.

Rinanto, A. (2005). Peranan Media Audi Visual dalam Pendidikan. Yogyakarta: Yayasan Kanisius.

Rifai, A, dan Sudhana, N. (1991). Media Pengajaran. Bandung: Sinar Baru.

Safrina, R. (1999). Pendidikan Seni Musik. Jakarta : Depdikbud.

Sudjarwo. (2008). Beberapa Aspek Pengembangan Sumber Belajar. Jakarta: Mediatama Sarana Perkasa.

Syah sinaga, S. (2010). Pembelajaran di Taman Kanak-kanak malalui Lagu Anakanak: Kajian di TK Kota Semarang. A Final Report. Semarang: Universitas Negeri Semarang

Siagian, Sondang. (2007). Fungsi-fungsi Manajerial. Jakarta: PT. Bumi Aksara

Sudjana, Nana. (2002). Pembinaan dan Pengembangan Kurikulum di Sekolah. Bandung: Suara Baru Algesindo.

Sukmadinata, N.S. (2006). Metode Penelitian Pendidikan. Bandung: PT. Rosdakarya.

Sumaryanto, Totok. (2009). Menjadi Pembelajar Dengan Seni. Semarang: Universitas Negeri Semarang.

Suyanto dan Jihad, Asep. (2012). Calon Guru dan Guru Profesional. Yogyakarta: Multi Pressindo.

Tornton, L. \& Borton, P. Understanding The Reggio Approach Reflection on The Early Childhood. London: David Fullan.

Utomo, U. (2011). Pembelajaran Musik di Taman Kanak-Kanak (Music Learning in Child School). Harmonia: Journal Of Arts Research And Education, 5(3). doi:http://dx.doi.org/10.15294/ harmonia.v5i3.824. 